\title{
Species Diversity, Forest Community Structure and Regeneration in Banke National Park
}

\author{
Renu Napit \\ Department of Environmental Science, Khwopa College, Affiliated to Tribhuvan University, \\ Bhaktapur, Nepal. \\ e-mail: renu.napit1@gmail.com
}

\begin{abstract}
Banke national park, located in Banke district of western Nepal with an area of $550 \mathrm{sq} . \mathrm{km}$ was established as the tenth national park in 2010 A.D. Forest community structure, species diversity and natural regeneration were studied in the Park. A total of 1067 plots at every interval of $200 \mathrm{~m}$ were laid by line transect method for the study. In each plot three concentric rings of radii of $10 \mathrm{~m}, 5 \mathrm{~m}$, and $1 \mathrm{~m}$ were laid down for the study of trees, shrubs/saplings and herbs/seedlings respectively. The park was floristically rich with a total of 113 species of trees representing 57 genera and 28 families. Similarly 85 species of shrubs including climbers and 107 species of herbs including herbaceous climbers, and grasses were recorded. The obtained results from the size class distribution of the trees resembling inverse ' $\mathrm{J}$ ' shape indicated the good regenerating capability of the forest in the park. Fifty eight species of saplings and 40 species of seedlings of trees were recorded. From the quantitative study of the trees, the dominant species was Shorea robusta based on IVI (important value index) values, which was followed byTerminalia alata, Anogeissus latifolius, Mallotus philippinensis, etc. The total density stand (D) and basal area (BA) of the park were 291.48 trees/ha and $21.13 \mathrm{~m}^{2} /$ ha respectively. The highest density (D) and the basal area (BA) of $S$. robusta was 46.07 trees /ha and $5.07 \mathrm{~m}^{2} /$ ha respectively. The species diversity index $(\mathrm{H})$ of the tree species in BaNP was 1.32 , with species evenness $(\mathrm{J})$ of 0.64 and index of dominance $(\mathrm{C})$ of 0.08 . A total of seven forest community types were estimated in the Park. The size class distribution diagram of all trees showed right skewed (inverse $\mathrm{J}$ shaped) pattern indicating a good regenerating capability of the forest. The regeneration of S. robusta, T. alata and A. latifolius were higher in comparison to other tree species which was indicated by the higher seedlings and saplings density of them. S. robusta was the dominant with saplings density of 200.49 / ha and seedlings density of 27153.4 /ha.
\end{abstract}

Key words: abundance, distribution, dominance, seedling, sapling, vegetation

\section{Introduction}

Study of forest community structure is very essential in order to manage the forest resources in a sustainable basis, which includes essential features such as structural type, size, shape and both vertical and horizontal spatial distribution (Spies 1998). Forest structure is both a product of forest dynamics and a template for biodiversity and ecosystem function. Moreover, size-class distributions give better indication of long-term regeneration status than seedling counts (Vetaas 2000). Degradation of forests manifested through simplified forest structure, biodiversity loss and alteration of forest ecosystem processes and functions occurring in many places (Charnley and Poe 2007). Population structure, characterized by the presence of sufficient population of seedlings, saplings and young trees indicate a successful regeneration of forest species (Saxena \& Singh 1984). Regeneration pattern determines the species composition and stability in the future. Thus for the sustainability of forest, regeneration is important. The regeneration of plant depends mainly upon the average seed output, viability of seeds, seed dormancy, seed dispersal, seedling growth, vegetative growth and reproductive growth. Larger number and proper establishment of seedlings are the most suitable factors for the good regeneration. 
Government of Nepal declared Banke National Park as the $10^{\text {th }}$ National Park of Nepal in $12^{\text {th }}$ of July 2010. This park together with Bardia National Park provide large protected complex to conserve biodiversity and to support viable population of breeding tigers. The Banke NP is expected to aid in achieving Government of Nepal's goal to double the tiger numbers in Nepal by 2022. The forest belts covering the part of Banke, Bardia, and Dang districts along the Churia range and its foothills are still intact and represent the natural diversity of flora and fauna of the western Tarai.

Study of forest community structure is essential in order to manage the forest resources in a sustainable basis. Similarly, analyses of diversity of forest component, natural regeneration, are important variables to assess the forest status in terms of growing stock, dynamics, forest and sustainable management. Such information would help to facilitate for developing a management strategy of the forest. Prior to being Banke National Park, the area was under the jurisdiction of district forest office, and it went through a series of disturbances (like- illegal logging, cattle grazing, cutting and lopping of fodder species) which otherwise could have reached the succession stage as in many other PAs of Nepal. Thus the present study was sought to inspect the status of forests, analyze species diversity and to assess the regeneration pattern of Banke National Park. The main objectives of this research are to study the vegetation composition and to analyze the quantitative characters of vegetation in the Park, to scrutinize the forest community structure as well as to classify the forest community types, to analyze natural regeneration status of forest in the park.

\section{Study area}

The Banke National Park (BaNP) is located in the MidWestern Development Region, in Banke district of Nepal. It is located between $81^{\circ} 39^{\prime} 29^{\prime \prime}$ to $82^{\circ} 12^{\prime} 19^{\prime \prime}$ east longitude and $27^{\circ} 58^{\prime} 13^{\prime \prime}$ to $28^{\circ} 21^{\prime} 26^{\prime \prime}$ north latitude. The total area of the park is $550 \mathrm{sq} . \mathrm{km}$. with the buffer zone of 343 sq. km, with headquarters in Obary (Mahadevpuri-7, Banke) and sector office at Chepang and Kusum. The park is linked with transboundary landscape that joins Suhelwa Wildlife Sanctuary of India through national and community forests towards south. It is connected with Bardia National Park of Nepal towards west which further links with Katerniaghat Wildlife Sanctuary in India via Khata corridor, national forest and community forests. It covers parts of Banke (77\%), Bardia, Dang and Salyan (23\%) districts of the nation.

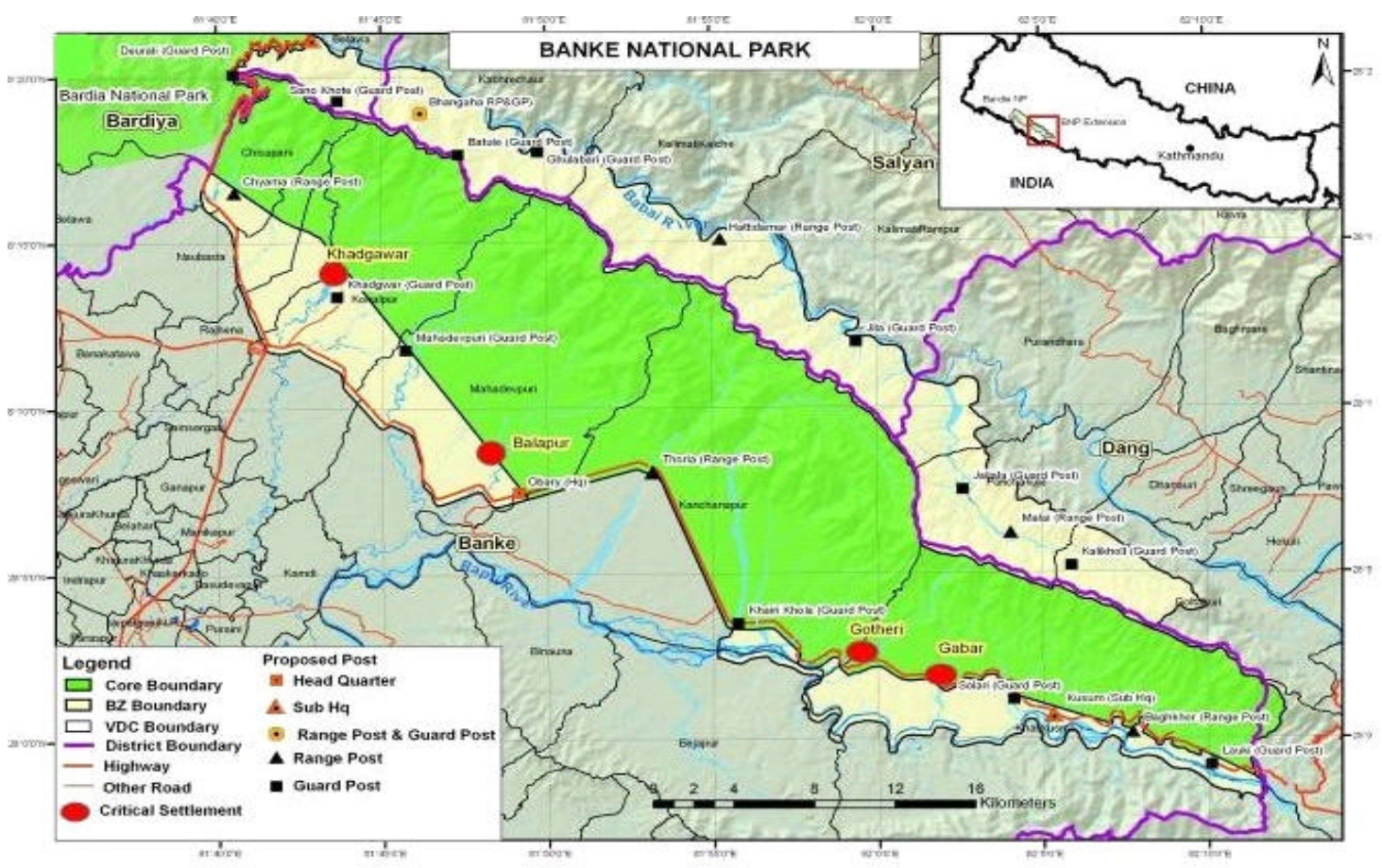

Fig. 1. Study area (Banke National Park) 
The topography of the BaNP is very diverse, with flood plains, river valleys and gorges, and the Churia hills in between Rapti river in the south and Babai river in the north. Its highest elevation is $1247 \mathrm{~m}$ at Kuine ridge/ Phurksalli and the lowest elevation is $153 \mathrm{~m}$ near Dhakeri. This Park has a sub-tropical monsoonal climate with summer monsoon from mid June to early October followed by a relatively long, cold and dry winter. The temperature variation is high ranging from $10^{\circ} \mathrm{C}$ to $45^{\circ} \mathrm{C}$ in May/June with an average temperature of $23^{\circ} \mathrm{C}$. The hot humid days gives way to monsoon rains that lasts until September.

This park has two bioclimatic zones -tropical and subtropical zones with an array of eight ecosystem types - sal forest, deciduous riverine forest, savannahs and grasslands, mixed hardwood forest, flood plain community, Bhabar and foot hills of Chure range. There are 124 sp. of plants ( 88 trees and climbers and 36 shrub species), 34 mammals, more than 300 birds, 24 reptiles, 7 amphibians and 58 fish species. Ninety percent natural forest coverage is composed of mainly Sal, Karma, Khair and Sissoo (MFOSC, DNPWC and WWF, 1998). BaNP has 14 VDCs as buffer zone from Banke, Dang, Salyan and Surkhet districts. There are about 4,861 households with 35,712 populations residing in buffer zone. About $90 \%$ of the economy of people depends on agriculture and rest $10 \%$ on trade and labor. The major issues found in this area aredeforestation, encroachment, remoteness, and poverty.

\section{Methodology Sampling methods}

The park was divided into 17 equal grids each of $8 \mathrm{X}$ 8 sq. km (Fig. 2). The grid was again divided into 16 sub grids of area each 2 X 2 sq. km (Fig. 3) (WWF 2011). GPS was used to locate the study areas. The data on species were determined in each alternate sub grid by means of sampling in three concentric circular plots $(10 \mathrm{~m}, 5 \mathrm{~m}$, and $1 \mathrm{~m}$ radii as in Fig. 5) along predefined clusters of line transects in equal distance of $200 \mathrm{~m}$ (Fig. 4). Thus, there were $8 \mathrm{sub}$ grids in each grid for survey. In total 107 sub grids were studied in which 1067 plots were laid, excluding the settlement areas.

Two systematic data forms were used to record topography, terrain type, and vegetation quantitative data. The girths or circumferences of each tree in the sampling plots were measured by a measuring tape. The total number of tree species diameter at breast height $1.37 \mathrm{~m}$; (dbh e" $10 \mathrm{~cm})$ was noted at each sampling plot of $10 \mathrm{~m}$ radius concentric ring. The number of shrub species was counted along each $5 \mathrm{~m}$ radius concentric ring and herbs and grasses were counted along each $1 \mathrm{~m}$ radius concentric ring. Regeneration of tree species was calculated by counting the seedlings (height $<20$ $\mathrm{cm})(1 \mathrm{~m}$ radius concentric ring) and saplings (height $>20 \mathrm{~cm}$ ) along $5 \mathrm{~m}$ radius concentric ring following Sundriyal and Sharma (1996).
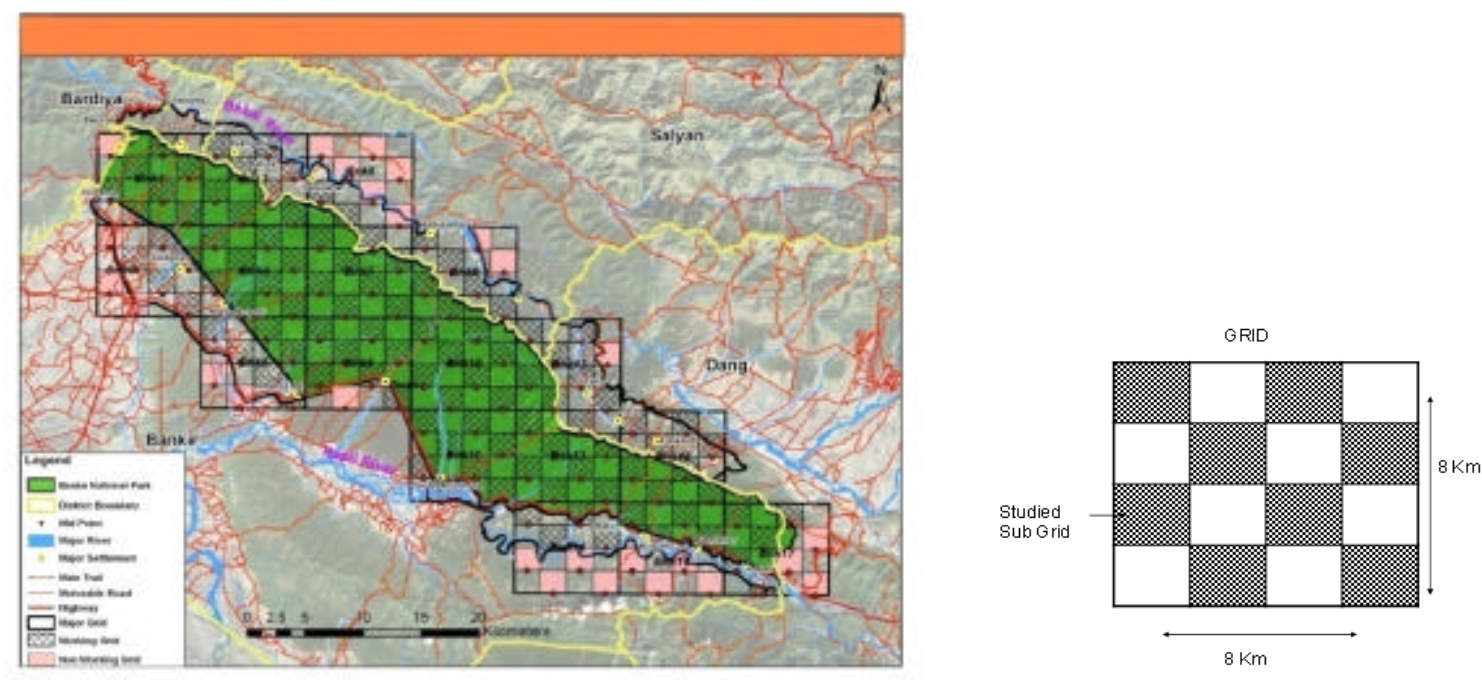

Fig. 2. Division of whole national park into 17 grids

Fig.3.The grid design for vegetation sampling 


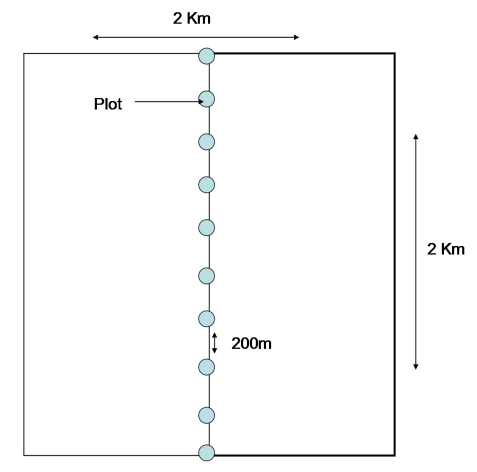

Fig. 4. Plot sampling in a sub grid in each distance of $200 \mathrm{~m}$

All the species found in the plot were identified in the field as far as possible. For the species, which could not be identified in the field, herbarium specimens were prepared to be identified later by experts and according to the identification keys, relevant texts and other standard literature. Botanical name and author citation was made according to Press (2001). Doubtful specimens were tallied with the specimens in Tribhuvan University Central Herbarium (TUCH) and National Herbarium and Plant Laboratories, Godawari.

\section{Data analysis Quantitative analysis}

Data obtained from all the plots of each grid were combined with respect to trees, shrubs, saplings and seedlings of trees, herbs and grasses. The species richness and species diversity index were determined. Then the ecological parameters such as density, relative density, frequency, relative frequency, and basal area were analyzed quantitatively from acquired vegetation data by Microsoft Office Excel program. Their relative values were summed up to represent or calculate the important value index (IVI) of each tree species following Mueller-Dombois and Ellenberg (1974) and Zobel (1987). Further, Correspondence Analysis (Biodiversity Program Professional Version 2) was used to classify the forest community types of the park.

\section{Regeneration status of the forest}

Density of saplings and seedlings of each tree species were determined. For the analysis of size class diagram, $\mathrm{dbh}$ (diameter at breast height) of all the tree species were categorized into diameter classes with interval of $10 \mathrm{~cm}$ where dbh classes and density of each dbh class

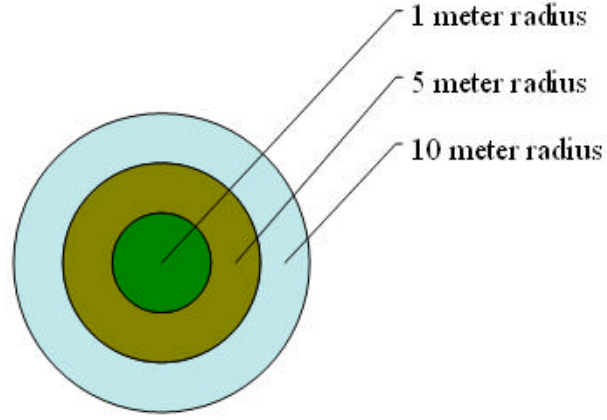

Fig. 5. Layout of the concentric circular sample plots of $10 \mathrm{~m}, 5 \mathrm{~m}$ and $1 \mathrm{~m}$ radii

were used to develop size class distribution diagram. The density and relative density of each tree, sapling and seedling of each species were also determined to estimate the population structure of ten dominant tree species of the park.

\section{Results and Discussion \\ Vegetation composition and quantitative vegetation analysis \\ Vegetation composition}

A total of 113 species of tree, representing 57 genera and 28 families were recorded within the studied area. Similarly 85 species of shrubs including climber and 107 species of herbs including herbaceous climbers, and grasses were recorded. The uppermost canopy layer was formed by tall trees like Shorea robusta, Terminalia alata, Anogeissus latifolia, Buchanania latifolia, Semecarpus anacardium, etc. The subcanopy was constituted by Diospyros tomentosa, Diospyros malabarica, Cassia fistula, Mallotus philippensis, Wendlandia spp., etc. The third layer was made up of shrub species like Calotropis gigantean, Woodfordia fruticosa, Euphorbia hirta, Mimosa rubicaulis, Adhatoda vasica (Justicia adhatoda), Thespesia lampas, Buddleia paniculata, Colebrookea oppositifolia, etc. and fourth and the last layer is ground layer made by herbaceous species like Eragrostis cyanosuroides, Cyperus rotundus, Eulaliopsis binnata, Achyranthes bidentata, Cissampelos pareira, Phoenix humilis, etc. and seedlings of woody species. Invasive species found in the area were Lantana camara, Ipomoea fistulosa, etc. 


\section{Quantitative vegetation analysis}

Species diversity index $(H)$, species richness and species evenness

The species diversity of the BaNP was 1.32 (Table 1). In the comparative study of sp. diversity index within the studied grids, the highest value of $\mathrm{sp}$. diversity was found in grid 10 i.e. (H) 1.29 , which was followed by grid 1 and 11 with diversity index of 1.24 in both (Table 2). The lowest value of diversity index was found in grid $6(\mathrm{H}=0.66)$.
Similarly the species richness of the park was estimated 113. Grid wise it range from 18 to 50 in grid 6 and grid 10 respectively. Species evenness of the park was found to be 0.64 . Grid wise it ranged from 0.7 to 0.85 . Lowest species evenness was found in grid $6(0.7)$ and highest in grid $17(0.85)$. The index of dominance was 0.08 in the whole park. The highest dominance was found to be 0.2 in grid 6 whereas the lowest index of dominance was 0.08 in grids 1 , 10,11 and 17.

Table 1. The quantitative analysis of the vegetation in whole BaNP

\begin{tabular}{l|l|l|l|l|l|l|c}
\hline $\begin{array}{l}\text { Whole N. } \\
\text { Park }\end{array}$ & $\begin{array}{l}\text { SP.Diversity } \\
(\mathrm{H})\end{array}$ & $\begin{array}{l}\text { Sp. } \\
\text { Richness }\end{array}$ & $\begin{array}{l}\text { Sp. } \\
\text { Evenness(J) }\end{array}$ & $\begin{array}{l}\text { Density } \\
(\text { no./ha) }\end{array}$ & $\begin{array}{l}\text { BA } \\
(\mathrm{m} 2 / \mathrm{ha})\end{array}$ & $\begin{array}{l}\text { Index of } \\
\text { dominance(C) }\end{array}$ & $\begin{array}{l}\text { Total stem no. } \\
\text { of ind. Trees }\end{array}$ \\
\hline & 132 & 113 & 0.64 & 291.48 & 21.13 & 0.08 & 9793 \\
\hline
\end{tabular}

Table 2. The quantitative analysis of the vegetation in studied 17 grids

\begin{tabular}{l|c|c|c|c|c|c|c}
\hline $\mathbf{S N}$ & $\begin{array}{c}\text { SP. } \\
\text { diversity } \\
\mathbf{( H )}\end{array}$ & Sp. richness & $\begin{array}{c}\text { Sp. evenness } \\
(\mathbf{J})\end{array}$ & $\begin{array}{c}\text { Density } \\
\text { (no./ha) }\end{array}$ & BA (m2/ha) & $\begin{array}{c}\text { Index of } \\
\text { dominance } \\
\text { (C) }\end{array}$ & $\begin{array}{c}\text { Total stem no. of } \\
\text { ind. trees }\end{array}$ \\
\hline $\mathbf{1}$ & 1.24 & 39 & 0.78 & 322.72 & 31.6 & 0.08 & 608 \\
$\mathbf{2}$ & 1.13 & 31 & 0.76 & 357.32 & 25.16 & 0.1 & 561 \\
$\mathbf{3}$ & 1.12 & 27 & 0.78 & 229.3 & 15.44 & 0.11 & 432 \\
$\mathbf{4}$ & 1.13 & 34 & 0.74 & 370.22 & 22.77 & 0.1 & 930 \\
$\mathbf{5}$ & 1.14 & 25 & 0.82 & 135.88 & 20.73 & 0.09 & 256 \\
$\mathbf{6}$ & 0.88 & 18 & 0.7 & 211.78 & 24.73 & 0.2 & 133 \\
$\mathbf{7}$ & 1.2 & 42 & 0.74 & 339.57 & 23.15 & 0.1 & 853 \\
$\mathbf{8}$ & 1.2 & 44 & 0.73 & 376.25 & 35.69 & 0.11 & 827 \\
$\mathbf{9}$ & 1.2 & 35 & 0.78 & 282.4 & 17.23 & 0.1 & 532 \\
$\mathbf{1 0}$ & 1.29 & 50 & 0.76 & 286.23 & 26.95 & 0.08 & 719 \\
$\mathbf{1 1}$ & 1.24 & 38 & 0.78 & 369.03 & 30.93 & 0.08 & 927 \\
$\mathbf{1 2}$ & 1.12 & 32 & 0.74 & 273.43 & 11.49 & 0.12 & 601 \\
$\mathbf{1 3}$ & 1.23 & 43 & 0.75 & 236.07 & 13.3 & 0.09 & 593 \\
$\mathbf{1 4}$ & 1.06 & 26 & 0.75 & 371.02 & 26.53 & 0.12 & 1966 \\
$\mathbf{1 5}$ & 1.16 & 35 & 0.75 & 220.54 & 9.99 & 0.11 & 554 \\
$\mathbf{1 6}$ & 1.1 & 26 & 0.78 & 318.47 & 24.41 & 0.1 & 400 \\
$\mathbf{1 7}$ & 1.19 & 25 & 0.85 & 254.8 & 10.66 & 0.08 & 400 \\
\hline
\end{tabular}

\section{Inde $x$ of dominance}

The study of index of dominance $(C)$ showed that the highest index of dominance was recorded in the grid 6 with 0.2 . Lowest index of dominance was found in grid 1, 10, 11 and 17; i.e. 0.08. Grid 12 and
14 had index of dominance of 0.12 . Grids 3,8 , and 15 had index of dominance of 0.11 ; whereas grids 2,4 , 7, 9 and 16 had 0.1 . Grids 5 and 13 had index of dominance of 0.09 . 


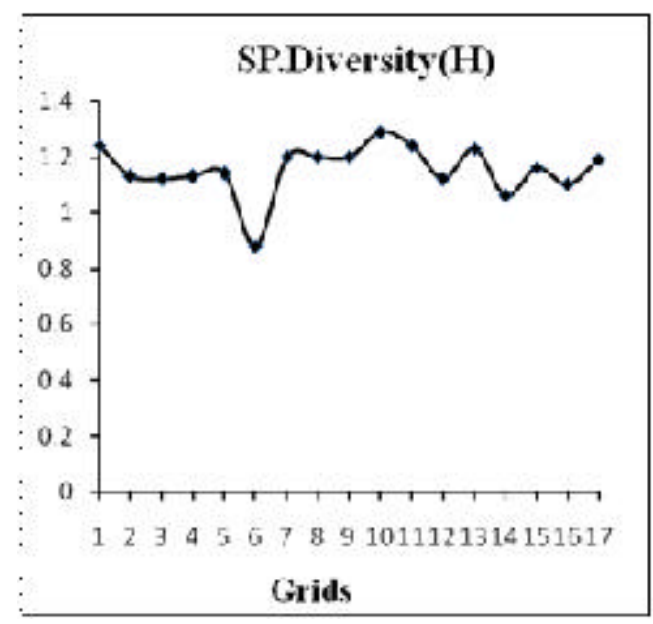

A

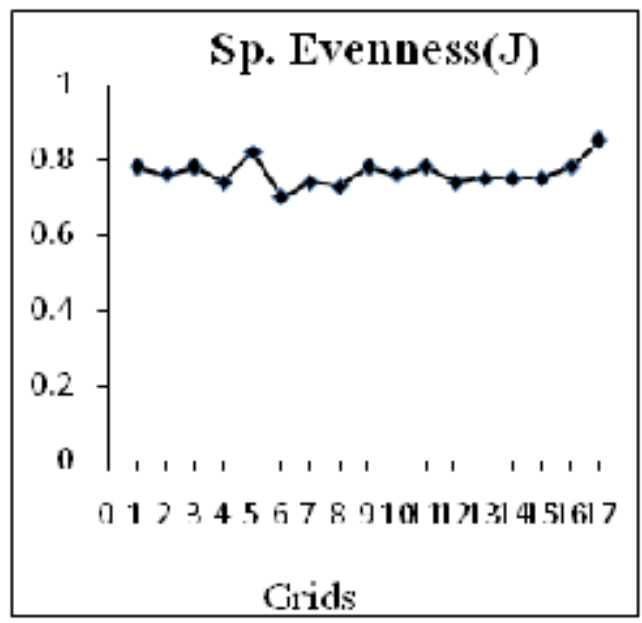

B

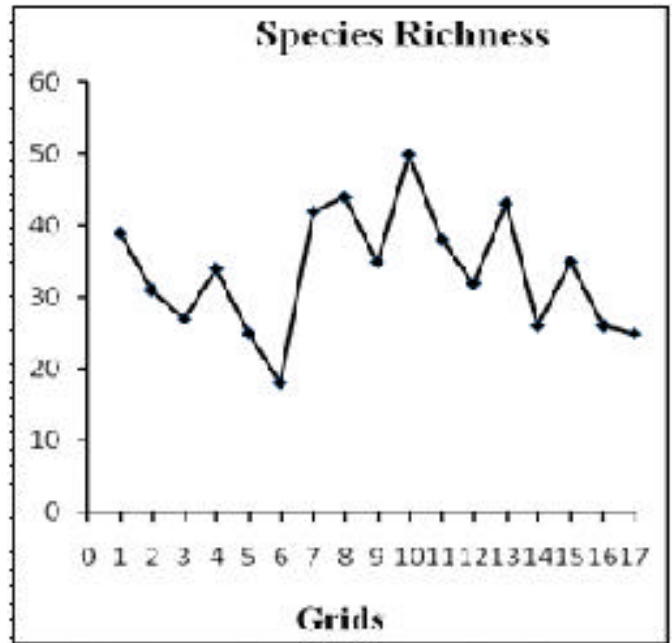

C

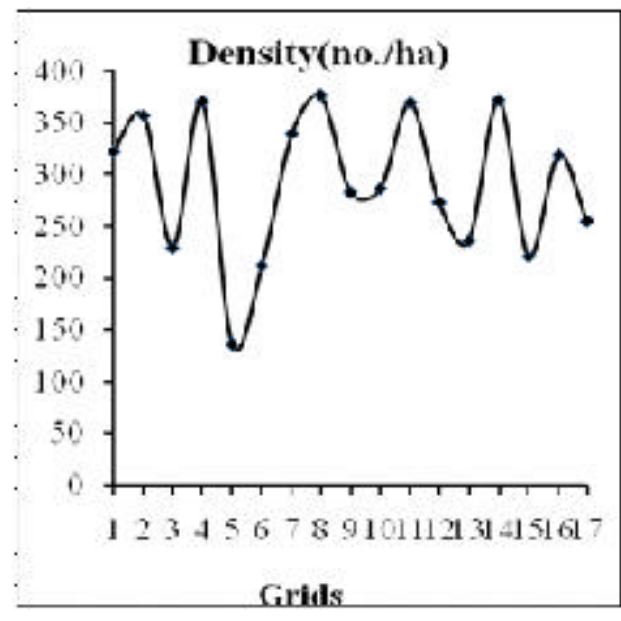

D

Index of dominance(C)

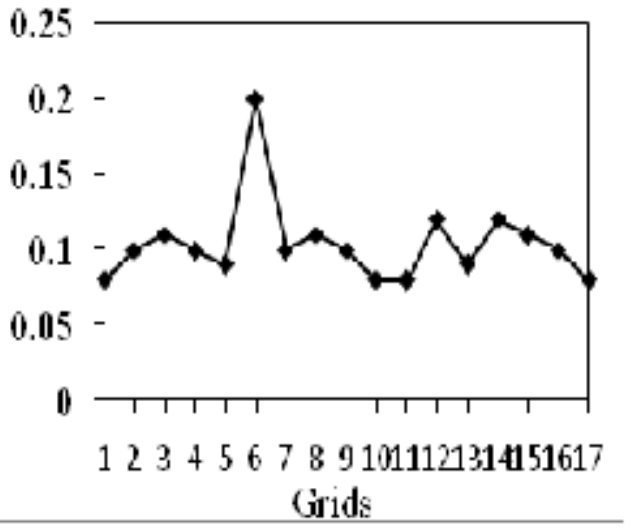

$\mathrm{E}$

Fig. 6. Quantitative analysis; species diversity index $(\mathrm{H})$ (A), species evenness (J) (B), species richness (C), density (D), index of dominance(C) (E) of studied 17 grids of BaNP

\section{Forest community structure}

The study on density of trees/ha in the studied sub grids showed that the density of trees ranged from 82.8 - 633.8 trees /ha (Table5). The highest density was found in sub grid $1 \mathrm{~A}$, with a density of 633.8 trees /ha, followed by 573.2 trees /ha in sub grid 12B, then by sub grid $11 \mathrm{~F}$ with density of 563.7 trees/ha. The lowest tree densities were found in sub grids $15 \mathrm{~F}$ and $5 \mathrm{~F}$ with densities of 89.2 trees /ha and 82.8 trees /ha respectively.

The total stand density (D) and basal area (BA) in the whole park were 291.48 trees/ha and $21.13 \mathrm{~m} / \mathrm{ha}$ 
respectively (Table 2). The highest density was found in grid 8 with density (376.25. / ha), followed by grid 14 with (371.02 / ha) and then by grid 4 with (370.22 / ha). The highest density was found to be of $S$. robusta i.e. 46.07 trees/ha (Table 3). While T. alata had 42.86 07 trees/ha and A. latifolius had density of 42.9207 trees/ha. The basal area (BA) estimated for S. robusta was $5.07 \mathrm{~m}^{2} /$ ha. T. alata had BA of $4.49 \mathrm{~m}^{2} /$ ha and $A$. latifolius had $2.49 \mathrm{~m}^{2} /$ ha of BA. The highest BA was found in grid 8 with basal area of $35.69 \mathrm{~m}^{2} / \mathrm{ha}$, followed by grid $1\left(31.6 \mathrm{~m}^{2} / \mathrm{ha}\right)$ and then by grid $11\left(30.93 \mathrm{~m}^{2} /\right.$ ha). Girth sizes of trees at breast height (circumference) ranged from $0.1-5.25 \mathrm{~m}$ (diameter of $0.05 \mathrm{~m}-1.67 \mathrm{~m}$ ). The greatest circumference of $5.25 \mathrm{~m}$ (diameter of 1.67 $\mathrm{m}$ ) tree was found as $P$. roxburghii followed by Ficus bengalensis of $5.05 \mathrm{~m}$ (diameter of $1.61 \mathrm{~m}$ ) and then by $S$. robusta of circumference $4.98 \mathrm{~m}$ (diameter of $1.59 \mathrm{~m})$.

The important value index (IVI) varied from 0.08 ( $Z$. mauritiana) to 46.18 ( $S$. robusta). The highest IVI value was that of S. robusta (46.18) followed byT.alata
(42.60) and then by Anogeissus latifolius (32.54). Based on IVI values, $S$. robusta, followed by $T$. alata, A. latifolius, M. philippinensis, A. catechu, D. malabarica, B. latifolia, S. cumini, G. pinnata and $O$. dalbergiodes were found to be the ten most dominant species in Banke national park.

\section{Frequency of occurrence}

The frequency of occurrence of tree species of the park ranged from 0.93 to $89.72 \%$ (Table 3 ). The highest frequency was found to be of $T$. alata with frequency $89.72 \%$, followed by $S$. robusta with frequency $85.98 \%$ and then by A. latifolius with frequency $81.31 \%$. The lowest frequency was found to be of $0.93 \%$ of many other tree species.

\section{Species richness curve}

Species richness curve for the whole park showed a sharp increase in tree species richness with increase in sampling plot size (fig. 7). It explains that the probability of increasing of species richness was high as the sampling size increased.

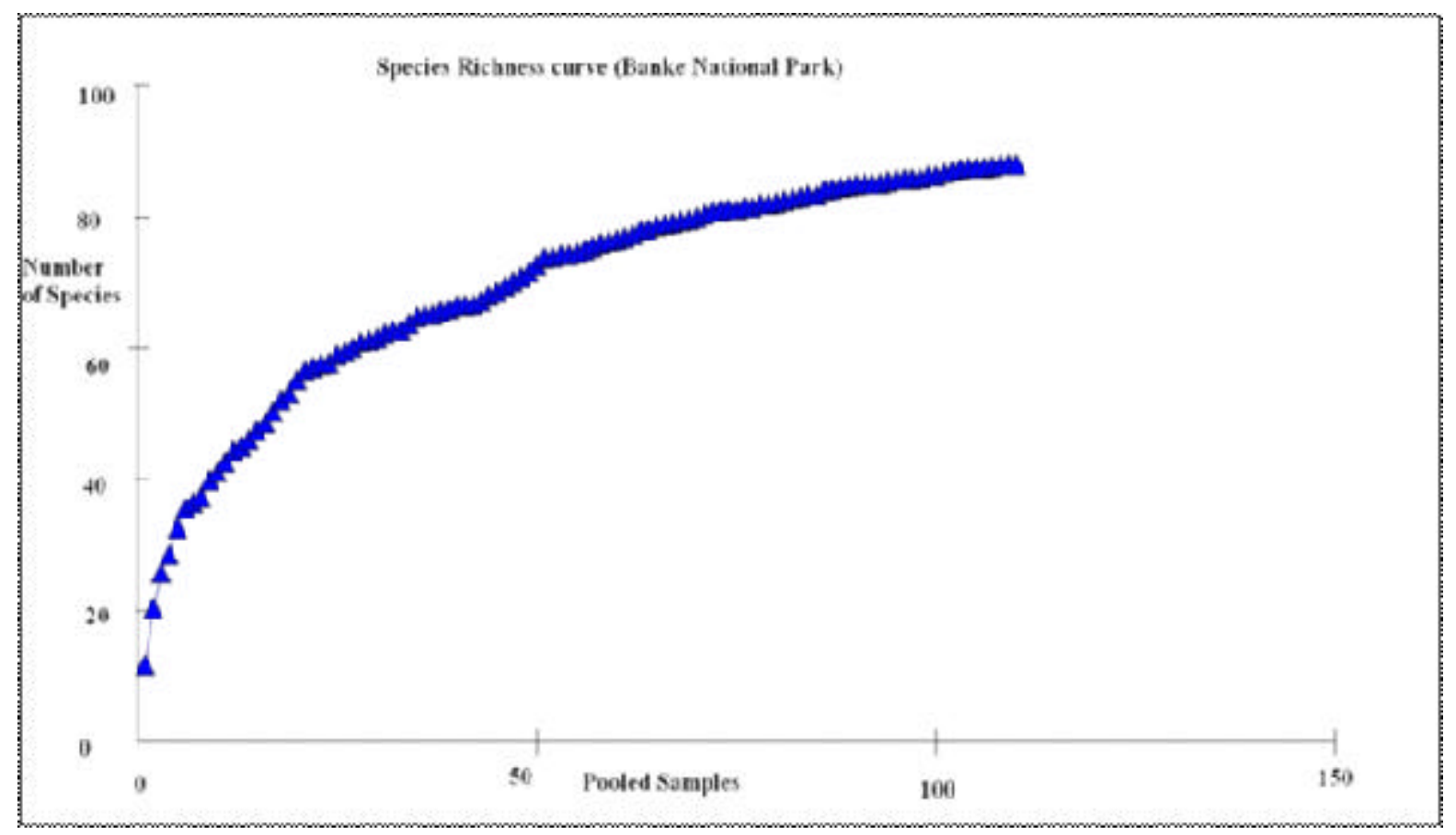

Fig. 7. Species richness curve of the vegetation of BaNP

\section{Unique species richness curve}

The slope of the unique species richness curve for each study site declined as sampling area increased
(Fig.8). From this observation it could be estimated that the uniqueness of the species of the study area decreased as the sampling size increased. 
Nepal Journal of Science and Technology Vol. 16, No.1 (2015) 17-30

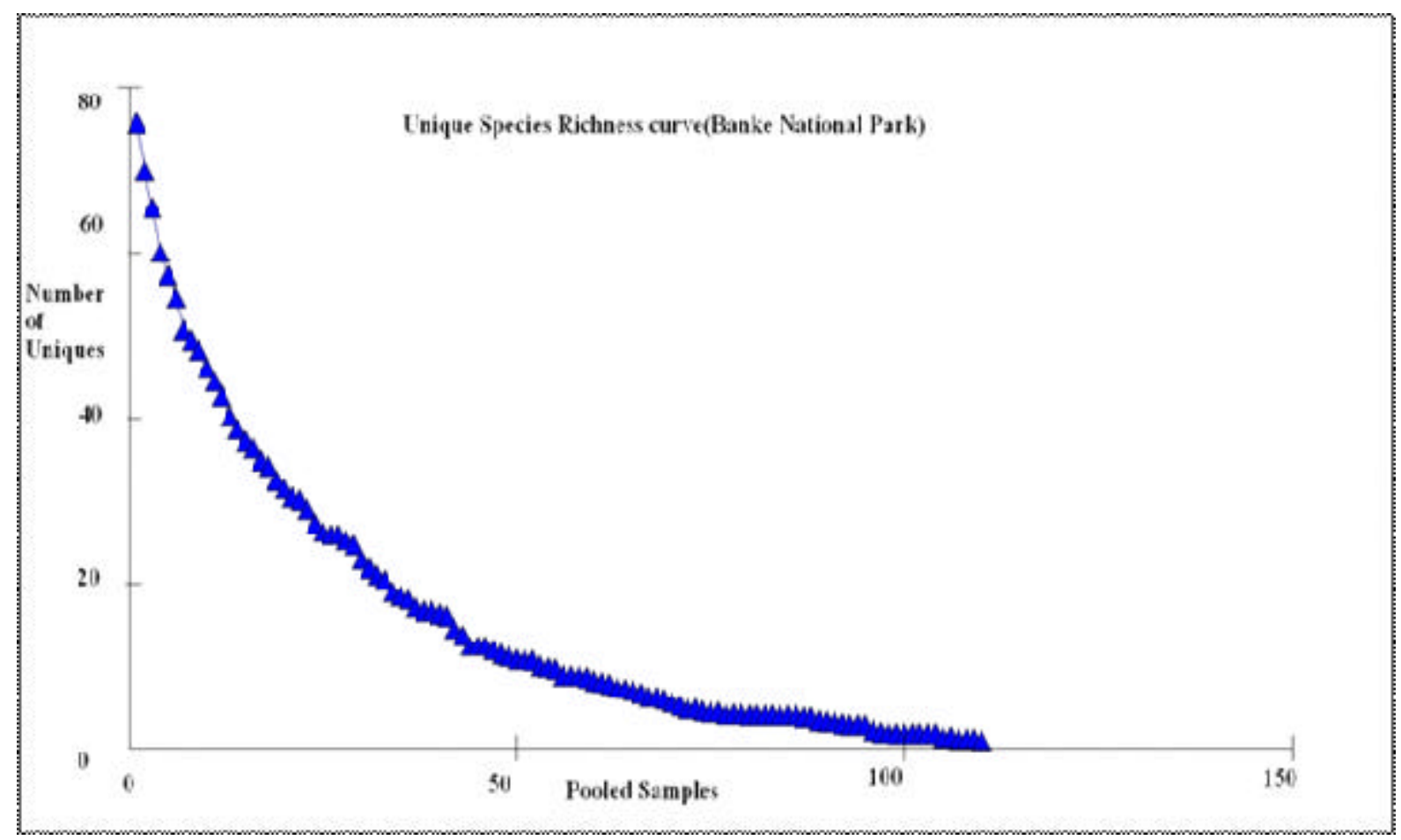

Fig. 8. Unique species richness curve of the vegetation in BaNP

\section{Sapling and shrub layer}

The sapling layer in the studied sub grids ranged from 25.5 - 5808.9 trees /ha. The highest sapling was found in sub grid $4 \mathrm{C}$ with sapling density of 5808.9 /ha. It was followed by sub grid $4 \mathrm{~F}$ with density 4203.8 /ha. The third highest density of saplings of the trees was found in sub grid $2 \mathrm{C}$ with 4025.5 /ha of the saplings. The lowest sapling density was found in sub grid $15 \mathrm{G}$ with density of $25.5 /$ ha. In the sub grids $8 \mathrm{E}, 10 \mathrm{~B}, 13 \mathrm{~A}, 13 \mathrm{~F}, 13 \mathrm{H}, 15$ $\mathrm{A}$ and $17 \mathrm{~A}$ there was no any saplings found.

The shrub layer vegetation was less flourished in species richness than trees and herbs with 85 shrub species including climbers. The quantitative study in the sub grids revealed that the proportion of shrub density was higher than the trees. The shrubs density ranged from 25.5 to 2369.4 /ha (Table 5). The highest dense sub grid with shrub density was found to be sub grid 8D with density of 2369.4 / ha, followed by sub grid $2 \mathrm{E}$ ( 1834.4 / ha), and then by sub grid 5G (1783.4 / ha). Lowest densities of shrub were found in sub grids $7 \mathrm{H}$ and $17 \mathrm{D}$ with only
25.5 / ha. There was no shrub found in the sub grids $13 \mathrm{D}$ and $13 \mathrm{G}$.

\section{Seedling and herb layer}

The seedling proportion was found to be more flourished than any other vegetation layer in the park. The density of seedling ranged from 636.9 59235.7 /ha. The sub grid 8D was found to be most dense with tree seedlings than any other sub grid with density of $59235.7 /$ ha, followed by sub grid $2 \mathrm{E}$ with 45859.9 / ha and then by sub grid 5G with density of $44586 / \mathrm{ha}$. The lowest densities of seedlings were found in sub grids $7 \mathrm{H}$ and $17 \mathrm{D}$ with density of only 636.9 /ha. In sub grids $13 \mathrm{D}$ and $13 \mathrm{G}$ there was no found of any tree seedlings. The studied park, total 107 species of herbs was recorded. From the record the most frequently present herb species were Eragrostis cyanosuroides, Cyperus rotundus, Eulaliopsis binnata, Achyranthes bidentata, Cissampelos pareira, Phoenix humilis, Urena lobata, Desmodium confertum, Saccharum spontaneum, Dipsacus mitis, Eragrostis tenell, Trachelospermum lucidum, Asparagus racemosus, Eulaliopsis binata, etc. 
Renu Napit/Species Diversity, Forest Community

Table 3. Trees, saplings and seedlings density in studied sub grids of BaNP

\begin{tabular}{|c|c|c|c|c|c|c|c|c|c|}
\hline $\begin{array}{l}\text { Sub } \\
\text { Grids }\end{array}$ & $\begin{array}{l}\text { Trees } \\
\text { density } \\
\text { (no./ha) }\end{array}$ & $\begin{array}{l}\text { Sapling } \\
\text { density } \\
\text { (no./ha) }\end{array}$ & $\begin{array}{l}\text { Seedling } \\
\text { density } \\
\text { (no./ha) }\end{array}$ & $\begin{array}{l}\text { Shrub } \\
\text { density } \\
\text { (no./ha) }\end{array}$ & $\begin{array}{l}\text { Sub } \\
\text { Grids }\end{array}$ & $\begin{array}{l}\text { Trees } \\
\text { density } \\
\text { (no./ha) }\end{array}$ & $\begin{array}{l}\text { Sapling } \\
\text { density } \\
\text { (no./ha) }\end{array}$ & $\begin{array}{l}\text { Seedling } \\
\text { density } \\
\text { (no./ha) }\end{array}$ & $\begin{array}{l}\text { Shrub } \\
\text { density } \\
\text { (no./ha) }\end{array}$ \\
\hline $\mathbf{1 A}$ & 633.8 & 1579.6 & 2229.3 & 89.2 & $9 H$ & 172.0 & 101.9 & 13375.8 & 535.0 \\
\hline 1B & 366.2 & 1146.5 & 15605.1 & 624.2 & $10 \mathrm{~A}$ & 321.7 & 700.6 & 9554.1 & 382.2 \\
\hline $1 \mathrm{C}$ & 519.1 & 433.1 & 5414.0 & 216.6 & $10 B$ & 197.5 & 0.0 & 7643.3 & 305.7 \\
\hline $1 D$ & 175.2 & 305.7 & 34394.9 & 1375.8 & $10 \mathrm{C}$ & 315.3 & 675.2 & 12738.9 & 509.6 \\
\hline $1 E$ & 324.8 & 356.7 & 5414.0 & 216.6 & 10D & 433.1 & 777.1 & 20382.2 & 815.3 \\
\hline $1 F$ & 200.6 & 394.9 & 15286.6 & 611.5 & $10 E$ & 455.4 & 76.4 & 6051.0 & 242.0 \\
\hline $1 G$ & 200.6 & 1248.4 & 17515.9 & 700.6 & $10 F$ & 200.6 & 394.9 & 9554.1 & 382.2 \\
\hline 2B & 324.8 & 3261.1 & 43630.6 & 1745.2 & 10G & 229.3 & 611.5 & 9235.7 & 369.4 \\
\hline $2 \mathrm{C}$ & 394.9 & 4025.5 & 15923.6 & 636.9 & $10 \mathrm{H}$ & 152.9 & 828.0 & 24840.8 & 993.6 \\
\hline $2 E$ & 273.9 & 879.0 & 45859.9 & 1834.4 & $11 \mathrm{~A}$ & 458.6 & 586.0 & 10191.1 & 407.6 \\
\hline $2 F$ & 551.0 & 3630.6 & 16560.5 & 662.4 & 11B & 136.9 & 624.2 & 7006.4 & 280.3 \\
\hline $2 G$ & 519.1 & 713.4 & 14968.2 & 598.7 & $11 \mathrm{C}$ & 181.5 & 1273.9 & 7324.8 & 293.0 \\
\hline $3 \mathbf{A}$ & 283.4 & 713.4 & 19426.8 & 777.1 & 11D & 506.4 & 1898.1 & 26433.1 & 1057.3 \\
\hline 3B & 289.8 & 152.9 & 11146.5 & 445.9 & $11 E$ & 551.0 & 917.2 & 2547.8 & 101.9 \\
\hline 3C & 273.9 & 369.4 & 7643.3 & 305.7 & $11 F$ & 563.7 & 254.8 & 7006.4 & 280.3 \\
\hline 3D & 273.9 & 1172.0 & 8280.3 & 331.2 & $11 G$ & 149.7 & 1019.1 & 8917.2 & 356.7 \\
\hline $3 F$ & 114.6 & 254.8 & 9872.6 & 394.9 & 11H & 420.4 & 738.9 & 18471.3 & 738.9 \\
\hline $3 \mathbf{H}$ & 172.0 & 917.2 & 11146.5 & 445.9 & $12 A$ & 238.9 & 407.6 & 5414.0 & 216.6 \\
\hline $4 \mathrm{~A}$ & 261.1 & 2484.1 & 11146.5 & 445.9 & $12 B$ & 573.2 & 777.1 & 10191.1 & 407.6 \\
\hline $4 B$ & 305.7 & 2789.8 & 6369.4 & 254.8 & $12 C$ & 133.8 & 343.9 & 2547.8 & 101.9 \\
\hline $4 C$ & 385.4 & 5808.9 & 17515.9 & 700.6 & 12D & 226.1 & 318.5 & 23885.4 & 955.4 \\
\hline 4D & 245.2 & 2089.2 & 28980.9 & 1159.2 & $12 F$ & 289.8 & 254.8 & 6687.9 & 267.5 \\
\hline $4 E$ & 414.0 & 993.6 & 39808.9 & 1592.4 & $12 G$ & 162.4 & 242.0 & 8917.2 & 356.7 \\
\hline $4 F$ & 442.7 & 4203.8 & 11146.5 & 445.9 & $12 \mathrm{H}$ & 343.9 & 152.9 & 6051.0 & 242.0 \\
\hline 4G & 509.6 & 1465.0 & 7643.3 & 305.7 & 13A & 232.5 & 0.0 & 2229.3 & 89.2 \\
\hline $4 H$ & 414.0 & 3248.4 & 30254.8 & 1210.2 & 13B & 207.0 & 1172.0 & 7006.4 & 280.3 \\
\hline $5 B$ & 159.2 & 420.4 & 7643.3 & 305.7 & 13C & 254.8 & 1388.5 & 21337.6 & 853.5 \\
\hline $5 \mathrm{C}$ & 159.2 & 891.7 & 10509.6 & 420.4 & 13D & 168.8 & 879.0 & 0.0 & 0.0 \\
\hline $5 E$ & 353.5 & 547.8 & 1592.4 & 63.7 & $13 E$ & 251.6 & 509.6 & 5414.0 & 216.6 \\
\hline $5 F$ & 82.8 & 356.7 & 955.4 & 38.2 & $13 F$ & 340.8 & 0.0 & 955.4 & 38.2 \\
\hline $5 G$ & 557.3 & 1974.5 & 44586.0 & 1783.4 & 13G & 238.9 & 38.2 & 0.0 & 0.0 \\
\hline $5 H$ & 175.2 & 420.4 & 7961.8 & 318.5 & 13H & 197.5 & 0.0 & 1910.8 & 76.4 \\
\hline $6 A$ & 156.1 & 420.4 & 7643.3 & 305.7 & $14 E$ & 235.7 & 76.4 & 4777.1 & 191.1 \\
\hline 6D & 270.7 & 777.1 & 8917.2 & 356.7 & $14 F$ & 509.6 & 127.4 & 5414.0 & 216.6 \\
\hline 7A & 331.2 & 458.6 & 7961.8 & 318.5 & 14G & 496.8 & 101.9 & 10191.1 & 407.6 \\
\hline 7B & 165.6 & 713.4 & 6051.0 & 242.0 & $14 H$ & 270.7 & 394.9 & 4458.6 & 178.3 \\
\hline $7 \mathrm{C}$ & 522.3 & 1057.3 & 23248.4 & 929.9 & 15A & 254.8 & 0.0 & 7961.8 & 318.5 \\
\hline 7D & 315.3 & 1617.8 & 24840.8 & 993.6 & 15B & 111.5 & 433.1 & 5414.0 & 216.6 \\
\hline $7 E$ & 328.0 & 535.0 & 8917.2 & 356.7 & $15 C$ & 273.9 & 38.2 & 6687.9 & 267.5 \\
\hline $7 F$ & 324.8 & 382.2 & 8280.3 & 331.2 & 15D & 172.0 & 178.3 & 9554.1 & 382.2 \\
\hline $7 G$ & 528.7 & 1465.0 & 9554.1 & 382.2 & $15 E$ & 334.4 & 254.8 & 7643.3 & 305.7 \\
\hline $7 \mathbf{H}$ & 226.1 & 471.3 & 636.9 & 25.5 & $15 F$ & 89.2 & 458.6 & 7643.3 & 305.7 \\
\hline $8 B$ & 449.0 & 853.5 & 19426.8 & 777.1 & 15G & 417.2 & 25.5 & 5732.5 & 229.3 \\
\hline $8 C$ & 232.5 & 777.1 & 3503.2 & 140.1 & $15 H$ & 111.5 & 458.6 & 5095.5 & 203.8 \\
\hline 8D & 531.8 & 2191.1 & 59235.7 & 2369.4 & $16 E$ & 238.9 & 1184.7 & 8598.7 & 343.9 \\
\hline $8 E$ & 238.9 & 0.0 & 6051.0 & 242.0 & $16 F$ & 426.8 & 394.9 & 21974.5 & 879.0 \\
\hline $8 F$ & 500.0 & 3082.8 & 24522.3 & 980.9 & 16G & 385.4 & 1006.4 & 7324.8 & 293.0 \\
\hline $8 G$ & 207.0 & 649.7 & 4458.6 & 178.3 & $16 \mathrm{H}$ & 222.9 & 89.2 & 14331.2 & 573.2 \\
\hline $8 H$ & 474.5 & 2509.6 & 15605.1 & 624.2 & 17A & 136.9 & 0.0 & 2547.8 & 101.9 \\
\hline 9A & 238.9 & 89.2 & 2547.8 & 101.9 & 17D & 270.7 & 127.4 & 636.9 & 25.5 \\
\hline $9 B$ & 328.0 & 1121.0 & 19745.2 & 789.8 & $17 F$ & 305.7 & 280.3 & 17515.9 & 700.6 \\
\hline $9 \mathrm{C}$ & 165.6 & 445.9 & 15923.6 & 636.9 & $17 G$ & 401.3 & 63.7 & 15605.1 & 624.2 \\
\hline 9D & 318.5 & 229.3 & 3821.7 & 152.9 & $17 H$ & 159.2 & 624.2 & 3184.7 & 127.4 \\
\hline $9 F$ & 496.8 & 305.7 & 3503.2 & 140.1 & & & & & \\
\hline
\end{tabular}




\section{Forest regeneration}

\section{Size class distribution}

The size-class distribution of stems for combined data of the park showed a right skewed and reverse $\mathrm{J}$ shaped distribution with continuous declining frequency in succeeding higher size class except for size class 20-30 cm (Fig 11).

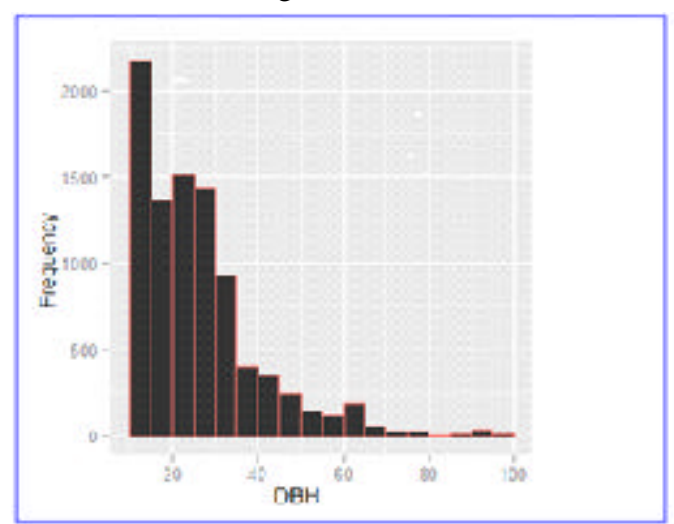

Fig. 9. Tree diameter distributions.

\section{Sapling/ seedling density}

A total of 58 species of saplings and 40 species of seedlings of trees were recorded in the study area. The density of seedlings (SeD), saplings (SD) (/ ha) and relative density (RD) were highest for Shorea robusta (with SD of 200.49/ha, SeD of 27153.4/ha and RD of 58.5) (Table 1). It was followed by Murraya koenigii with SD 125.36/ha and RD of 16.88 and then by Terminalia alata with SD of 92.62 /ha and RD of 12.47. While in SeD S. robusta was followed by $T$. alata with SeD of 5375.32 /ha and RD of 11.58 , which was followed by M. philippinensis with SeD of 4652.06 /ha and RD of 10.02 .

\section{Population structure of dominant tree species}

The population structure from the relative proportion of individual ten dominant tree species was depicted. The dominant tree species, S. robusta exhibited higher proportion of seedlings and comparatively low density of saplings and tree population. Same was the case for M. phillipensis. Whereas in the cases of A. latifolius, A. catechu, B. latifolia, O.dalbergoides, L. parviflora and $G$. pinnata had more proportions of trees than seedlings and saplings. Whereas $T$. alata and $D$. malabarica had quite equal proportions of seedlings, saplings and trees. This study has clearly shown the regeneration status of $S$. robusta was good as compared to other species in the BaNP. Thus, the ten dominant tree species differed greatly by proportions of density of seedlings, saplings and trees.

\section{Vegetation composition and quantitative analysis}

The number of shrub species was less than that of the number of tree species and herb species but the number of tree species was found higher than the number of herb species. Similarly in the study area the species evenness $(\mathrm{J})$ ranged from $0.7-0.85$. The high species number in the studied forest may be due to grazing by livestock, since mild disturbance might increase species richness (Connel 1978, Petraitis 1989). Niroula (2004), Shrestha (2003) and Bashyal (2005) found number of tree species less than that of shrub and herb species in Siwalik hills of Illam, Barandabhar Community Forest in Chitwan and tropical forest of Palpa district respectively. However, Karki (2004) found higher number of tree species than shrubs and herbs and higher species number of shrubs than herbs in the National park forest and community managed forest of western lowland (Bardia district) of Nepal.

The basal area is an important criterion for evaluating the timber production in forest ecosystem (Agrawal 1992), an indication of the natural fertility of the site (Bruening 1968) and maturity/age group of the forests. The estimated basal area of the studied grids of BaNP ranged from $9.99 \mathrm{~m}^{2} /$ ha (grid 15) to $35.69 \mathrm{~m}^{2} /$ ha (grid 8). The average BA of the park was $21.13 \mathrm{~m}^{2} /$ ha (Table 1 ). This average BA of the park was quite similar to several other reports for $S$. robusta forests, for example, BA of 29-36 $\mathrm{m}^{2} /$ ha for sal forests of Bardia National Park (Aryal 1997), $37.28 \mathrm{~m}^{2} /$ ha for Churia forest in eastern Nepal (Bhuju \& Yonzon 2000). But in contrast, it was lower than the value of BA $63.86 \mathrm{~m}^{2} /$ ha reported by Bashyal (2005) for tropical forest of Palpa district and $76 \mathrm{~m}^{2} / \mathrm{ha}$ as reported by Sejuwal (1994) in the $S$. robusta forest of Chitwan National Park.

The IVI of present study revealed that $S$. robusta, $T$. alata and A. latifolius were ecologically most important species and implied their high ecological success and competence over other less common associated species. Importance value index (IVI) in the BaNP was lower than IVI of Sal in a forest of Inner Terai (127) reported by Acharya (2007).

\section{Forest community structure}

Total density of the tree species in the study area ranged from 82.8 to 633.8 plants/ha which was very 
lower than in Churia forest of Rupandehi district (1092 - 1153 plants/ha), Marasini (2003) and in tropical forest of Palpa district (654 plants/ha), Bashyal (2005). But this value was higher than the value reported for sal forest by Giri (1999) in Bardia National Park (258 384 plants/ha). Lower total tree density in the present study area than the reported values for tropical forest might be due to over exploitation of the studied forest in the past. The highest densities were found to be of tree species like $S$. robusta, followed by A. latifolius T. alata, A. catechu, M. philippinensis, and B. latifolia etc. The low density of $O$. oojeinense may be due to its specific use for making plough by local people. The population of tree species like W. coriacea, Rhus succedanea, Psidium guajava, Grewia oppositifolia, Ficus spp. etc. were lower, so they were rare species of the park. So, such species should not be harvested during fodder collection by the locals or FUGs.

Seedlings of tree species like $S$. robusta and T. alata were frequently distributed with highest density among the seedlings of tree species. So it had high regeneration capacity and could exploit environmental conditions efficiently for seed germination and seedling establishment. The seedling density of the park ranged from 63459235.7 /ha. From the study it was found that the regeneration of the park was good. Rautiainen (1996) and Webb and Shah (2003) also reported good regeneration of Sal in the Terai of Nepal. However, regeneration potential of other trees was very low since the combined densities of seedlings of all other trees were very low as compared to $S$. robusta, $A$. latifolius and T. alata. Timilsina (2007) also reported low mean seedling density $\left(0.861 \mathrm{pl} / \mathrm{m}^{2}\right)$ of all other tree species in comparison toSal $\left(7.0462 \mathrm{pl} / \mathrm{m}^{2}\right)$ in Sal forest of western Terai.

Among the herbs, Phoenix humilis, Urena lobata, Cyperus rotundus, Eragrostis cyanosuroides, Cyperus cyperoides, Trachelospermum lucidum, were the most common species in the park. There were also some herbs with medicinal values in the park such as Asparagus racemosus, Cyperus rotundus, Dioscorea bulbifera, Mentha arvensis, Vetiveria zizanioides etc. The higher presence of Phoenix humilis and Urena lobata among the other grasses might be due to sunny and exposed area with open canopy because light availability was the most important environmental factor related to graminoid distribution (Pivello 1999).
Grasses had underground diffuse rhizomes and can thereby survive fire and other drought conditions (Bihari \& Lal 1989).

\section{Forest Regeneration}

The regeneration of $S$. robusta, $T$. alata and $A$. latifolius were recorded higher as compared to other tree species which was indicated by the higher seedling and sapling density of them, but highest was that of S. robusta. Canopy coverage was one of the best criteria for judging the status of the forest regeneration, as it might be responsible for light to reach forest floor. Since $S$. robusta is the light demanding species due to grazing resulted in a forest with more openings and gaps, leading to a higher abundance of large trees and fewer saplings which allow sufficient demander species. Solar radiation plays a vital role in the germination and establishment of seedlings. It has been reported that control of fire, grazing and human disturbance seems to have favored seedling survival and to escape from the so called Sal 'die- back' phenomena (Acharya 2001). Seedlings of S. robusta were abundantly present which might be due to thin litter and open canopy but other tree species had less number of seedlings.

Although the forest had high regeneration potential, all established seedling did not get the chance to develop into sapling stage which may be due to high human interference like grazing, trampling, forest fire, lopping and unsustainable harvesting of forest resources. All seedlings cannot survive due to harsh environmental condition and cannot compete with grasses for limited resources.

\section{Conclusion}

The park was mixed forest dominated by tree species $S$. robusta, $T$. alata and $A$. latifolius. Its floral diversity was fascinating with total 305 species of vascular plants with 113 trees, 85 shrubs and 107 herbs species. The regeneration potential of the park was high despite of high grazing and other human activities. The finding of 58 species of saplings and 40 species of seedlings of trees in the park and obtained result from the size class distribution of the trees resembling inverse ' $\mathrm{J}$ ' shape indicated the good regenerating capability in the park. Further, the domination of the shrub stratum by some tree saplings also indicated good regeneration and self-maintenance ability of the forest. 
Thus, the analysis of species composition, diversity, forest structure, and regeneration gave the clear picture on forest condition and dynamics of the park. This information would help to facilitate for developing a management strategy of the park in future. Effective forest conservation activities are necessary to maintain species diversity, forest regeneration and for sustainable management of forest in the park.

\section{Acknowledgements}

I am very grateful to WWF Nepal for providing necessary tools and volunteers for the field study. I express my appreciation to my supervisor Mr. Sanuraja Maharjan (Lecturer of Khowpa College) for his priceless advice and support to complete this study. I am thankful to Dr. Prakash Kumar Paudel (Research Scientist of Conservation Nepal) and my co-supervisor Ms. Sabita Malla (Senior Officer of Tal Project of WWF, Nepal) for their valuable suggestions. I am also very thankful to all of my friends as volunteers for helping me in data collection and field work.

\section{References}

Acharya, K.P. 2001. Natural regeneration potential of a mixed sal forest in central Nepal. Department of Forest Research and Survey. Research Leaflet No. $12,15 \mathrm{p}$.

Bhuju, D. and P. Yonzon, 2000. Floristic composition, forest structure and regeneration of the churia forest, eastern Nepal. A report submitted to Nature Conservation Society, Japan. Resources Himalayan, Kathmandu, Nepal. .

Bihari, M. and C.B. Lal. 1989. Species composition, density and basal cover of tropical rainforests. Tropical Ecology 30: 117-137.

Bruening, E. 1968. Forstliche Produktionslehre. Europaeische Hochschulschriften Bern-Franfurt.

Charnley, S. \& M. R. Poe, 2007. Community forestry in theory and practice: Where are we now? Annual Review of Anthropology, 36: 301-336.

Dhungana, M. 1997. Vegetation Analysis and Natural Regeneration Status of Hill SalForests in Panchkhal, Kavre Palanchok, Central Nepal. M.Sc. Thesis. Central Department of Botany, Tribhuvan University, Katmandu, Nepal.

Dobremez, J.F. 1976. Le Nepal: ecologique et phytogeomorphique. Centre National dela Rescherche Scientifique, Paris.

DPR. 2001. Flowering plants of Nepal (phanerogams). Department of Plant Resources, Kathmandu, Nepal.
Giri, A., B. Aryal, B. Bhattarai, S.K. Ghimire, K.K. Shrestha and P.K. Jha. 1999. Vegetation composition, biomass production and regeneration in Sal forests in the Bardia

National Park, Nepal. Nepal Journal of Science and Technology 1: 47-56.

Givnish, T.J. 1995. Plant Stems: Biochemical adaptation for energy capture and influence on species distributions. In: Plant Stems: Physiology and Functional Morphology (Ed. B.L. Gartner. Academic Press, San Diego. Pp.3-49.

Koop, H. 1989. Forest Dynamics-SILVI-STAR:A Comprehensive Monitoring System. Springer-Verlag, Berlin.

Marasini, S. 2003. Vegetation analysis of churiya forest in Rupandehi, Nepal. M.Sc. thesis. Central Department of Botany, Tribhuvan University, Kathmandu, Nepal. $91 \mathrm{p}$.

Ministry of Forests and Soil Conservation (MFSC), Department of National Parks and Wildlife Conservation (DNPWC), \& World Wildlife Fund (WWF) Kathmandu

Nepal 1998. Royal Bardia National park extension area five year operational

Plan 1998-2003. pp.2-12.

Ministry of Forests and Soil Conservation (MFSC) \& Department of National Parks and

Wildlife Conservation (DNPWC), Kathmandu Nepal. Management plan of Banke

National Park and its Buffer Zone 2010-2014.

Mueller-Dombois, D. and H. Ellenberg, 1974. Aims and Methods of Vegetation Ecology.

John Wiley and sons, U.S.A.

NBS. 2002. Nepal biodiversity strategy. Ministry of Forest and Soil Conservation, Kathmandu, Nepal. 170 p.

Niroula, R.K. 2004. Phytodiversity and soil study of Siwalik hills of Illam, Nepal. M.Sc. thesis. Central Department of Botany, Tribhuvan University, Kathmandu, Nepal. $78 \mathrm{p}$.

Pant, A. 1997. A comparative study of vegetation and natural regeneration of two hill sal forest ( $i$ ) community forest and (ii) degraded forest. M.Sc. thesis. Central Department of Botany, Tribhuvan University, Kathmandu, Nepal. 51 p.

Paudel, A. 2006. Assessment of the status of the floral diversity and the management practices (A case study in Hasantar community forest, Lalitpur). M.Sc. thesis. Central Department of Environmental Science, Tribhuvan University, Kathmandu, Nepal. 60 p.

Press, Cambridge University, Frodin David G., 2001. Guide to Standard Flores of the World, second edition.The Edinburgh Building, Cambridge CB2 2RU,UK,40West $20^{\text {th }}$ Street, New York NY 10011-4211, USA.

Rai, S.N., I.C. Dutta, S. Haque, B.B. Khanal, J.P. Chaurasia and I.P. Indu. 1999. Ecology and growth of S. robusta in central Nepal. In: Proceedings of International 
seminar on Sustainable forest management (Aug 31Sep 2 1998) Eds. P. Mathema, I.C. Dutta, M.A. Bala and S.N. Adhikari). Institute of Forestry, Tribhuvan University. Pokhara, Nepal pp. 117-125 .

Rautiainen, O. 1996. Regeneration status of Sal (Shorea robusta) in Bara District, Nepal.

Banko Jankari 6(1): 26-32.

Saxena, A.K. and J.S. Singh, 1984. Tree Population Structure of Certain Himalayan Forest

Associations and Implications Concerning their Future Composition, Vegetatio. 58: 61-69.

Saxena, A.K. and J.S. Singh, 1984. Population Structure of Forest of Kumaun Himalaya:

Implications for management, Journal of Environmental management, 19: 307-324.

Sejuwal, M. 1994. Above ground biomass estimation in tropical forest of Chitwan National Park. M.Sc. thesis. Central Department of Botany, Tribhuvan University, Kathmandu, Nepal. 60 p.

Shrestha, B.B. 2005. Fuel wood harvest, management and regeneration of two community forest in central Nepal. Himalayan Journal of Sciences 3:75-80.

Shrestha, R. 1997. Ecological study of natural and degraded forest in Chitrepani, Makwanpur district. Nepal. M.Sc. thesis. Central Department of Botany, Tribhuvan University, Kathmandu, Nepal. 113 p.

Singh, J.S. and Singh. 1992. Forest of Himalayan structure, functioning and impacts of man. Ganodaya Prakashan, Nainital, India. 257 p.
Spies, T.A. 1998. Forest structure: A key to the ecosystem. Northwest science.72. Special Issue No.2, USA.

Sundriyal, R.C. and E. Sharma, 1996. Anthropogenic pressure on tree structure and biomass in the temperate forest of Mamlay watershed in Sikkim. For Ecol Manage.

Timilsina, N., M.S. Ross, and Heinen, 2007. A community analysis of Sal (Shoera robusta Gaertn.) forests in the western Terai of Nepal. Forest Ecology and management 241 (1-3): 223-234.

TISC/NARMSAP/MFSC. 2002.Forest Vegetation types of Nepal. Ministry of Forests and Soil Conservation, Natural Resource Management Sector Assistance Program, Tree Improvement and Silviculture Component.

Vetaas, O. R. 2000. The effect of environmental factors on the regeneration of Quercus semecarpifolia in central Himalaya, Nepal. Plant Ecology 146: 137-144.

Webb, E.L. and R.N. Shah. 2003. Structure and diversity of natural and managed Sal (Shorea robusta Gaertn.) forest in the Terai of Nepal. Forest Ecology and Management 176: 337-353.

Zobel, D.B., P.K. Jha, M.J. Behan and U.K.R. Yadav.1987. A Practical Manual for Ecology, Ratna Book Distributors, Kathmandu, Nepal. 150 p. 
Nepal Journal of Science and Technology Vol. 16, No.1 (2015) 17-30 